\title{
HIERAROUIA CONSTITUCIONAL DO ESTATUTO DE ROMA
}

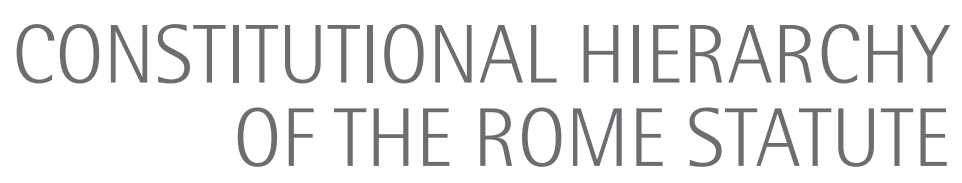

Andrea Flores

andreaflores.adv@gmail.com

Jodascil Gonçalves Lopes

jodascil@hotmail.com

Recebido: 2-9-2016

Aprovado: 15-9-2018

Sumário: 1 Introdução. 2 Incorporação e hierarquia dos tratados no Brasil. 2.1 Tratado de direito comum. 2.1.2 Teoria da Prevalência. 2.2. Tratados de matéria tributária. 2.3 Tratado Internacional de Direitos Humanos, aprovado pelo quórum qualificado. 2.4 Tratado Internacional de Direitos Humanos, quando não aprovado pelo quórum qualificado. 2.5 Hierarquia da Convençáo de Roma. 3 Considerações Finais. 4 Referências

\section{RESUMO:}

O presente trabalho discorre sobre as antinomias existentes entre as normas internas e internacionais, mais precisamente entre normas internacionais penais decorrentes do Estatuto de Roma e as normas insculpidas na Constituição Federal do Brasil de 1988, que dizem respeito ao Direito Penal Constitucional e ao Direito Penal Interno. Inicialmente, faz-se necessário classificar os tratados em comum, de matéria tributária, de direitos humanos aprovado com quorum qualificado e os de direitos humanos não aprovados pelo quórum qualificado. Tal análise se faz necessária para ser possível qual norma deve prevalecer ou ceder ante o tratado internacional. A pesquisa realizada foi exploratória, descritiva, bibliográfica e documental, com uma abordagem qualitativa e utilizando-se o método dedutivo. Diante dos argumentos levantados, é possível concluir que os tratados de direitos humanos, tendo ou

\section{ABSTRACT:}

This paper discusses the existing antinomy between domestic and international law, specifically between international criminal law arising from the Rome Statute and the inscribed standards in the Federal Constitution of 1988 Brazil, concerning the Constitution Criminal Law and the Criminal Law Internal. Initially it is necessary to be able to classify treated in common, in tax matters, human rights approved by qualified quorum and a human right not approved by a qualified quorum. Such analysis is necessary to be able to which standard should prevail or give in to the international treaty. The research was exploratory, descriptive, bibliographical and documentary, with a qualitative approach and using the deductive method. Before the arguments raised, it is possible to conclude that the human rights treaties, whether or not approval of a specific majority, makes up what we call constitutional block. This, 
não aprovação de quorum qualificado, compóe o que podemos chamar de bloco de constitucionalidade. Desta forma, o Estatuto de Roma, dentro do nosso ordenamento jurídico interno apresenta hierarquia constitucional.

\section{Palavras-chave:}

Antinomia. Normas internas. Normas internacionais. Estatuto de Roma. Constituição Federal. Bloco de Constitucionalidade. the Rome Statute within our domestic legal system has constitutional hierarchy.

\section{Keywords:}

Antinomy. Internal rules. International standards. Rome Statute. Federal Constitution. Constitutionality block.

\section{Introdução}

É possível que as antinomias normativas sejam quase tão antigas quanto as próprias normas. Seria impossível identificar qual a primeira antinomia. Entretanto, assim que surgiram duas normas válidas para um mesmo povo, tratando de um mesmo assunto, em um mesmo período, surgiram também as antinomias.

Tais antinomias podem ser constatadas no conflito instaurado entre normas internas, entre normas internacionais ou entre aquelas e estas. E, dentre as citadas, especial importância têm estas últimas para o presente trabalho, mais precisamente entre normas internacionais penais decorrentes do Estatuto de Roma e as normas insculpidas na Constituição Federal do Brasil de 1988, que dizem respeito ao Direito Penal Constitucional e ao Direito Penal Interno.

Para o bom entendimento do tema, primeiramente é necessário apontar, ao menos, três diferentes hierarquias conferidas aos tratados conforme sua matéria e procedimento de incorporação: hierarquia ordinária, supralegal e constitucional. Importante salientar que parte da doutrina defende existirem outros graus hierárquicos, conforme sua matéria ou prevalência da norma interna ou da norma internacional.

Contudo, será dada importância maior ao conflito existente no embate entre normas internas e normas internacionais; para que, em seguida, seja analisada a hierarquia que os tratados internacionais têm no Estado brasileiro, considerando a espécie e a matéria do tratado, para entáo concluir qual norma deve prevalecer ou ceder ante o tratado internacional.

Tal análise tem por objetivo estabelecer a hierarquia dos tratados de Direitos Humanos no ordenamento jurídico pátrio, em especial, do Estatuto de Roma.

\section{Incorporação e hierarquia dos tratados no Brasil}

Por opção metodológica, quando se fala em hierarquia dos tratados, está-se a falar em hierarquia do acordo internacional celebrado entre Estados soberanos, independente da nomenclatura utilizada: tratado, ato, convenção, acordo, etc.

A Constituição Federal não tratou de forma expressa da hierarquia dos tratados internacionais no ordenamento interno, ficando sob responsabilidade da doutrina e da 
jurisprudência tal tarefa, a qual ainda expressa grande dissensão - o que poderia ter sido evitado pelo constituinte originário.

Podemos apontar, ao menos, três diferentes hierarquias conferidas aos tratados conforme sua matéria e procedimento de incorporação: hierarquia ordinária, supralegal e constitucional. O assunto é controvertido, existindo ainda posição doutrinária que defende existirem outros graus hierárquicos, conforme sua matéria ou prevalência da norma interna ou da norma internacional.

\subsection{Tratado de direito comum}

O tratado internacional não foi contemplado no artigo 59 da Constituição Federal de 1988 que arrola as espécies normativas (emendas à Constituição, leis complementares, leis ordinárias, leis delegadas, medidas provisórias, decretos legislativos e resoluçôes).

Não estando o tratado internacional, portanto, contido no rol das fontes normativas escritas previstas na Constituição, sua incorporação ao ordenamento interno brasileiro se dá por um complexo processo que se inicia com a sua assinatura pelo plenipotenciário ${ }^{1}-$ ou aquele que tenha carta de plenos poderes ou ainda aquele que náo sendo o primeiro nem sendo o segundo, tenha seu ato confirmado pelo Estado que representou -, sendo depois aprovado pelo Congresso Nacional.

É o que se extrai do artigo 49, I, da Constituição Federal (doravante, simplesmente $\mathrm{CF}$ ), cujo teor diz ser “(...) de competência exclusiva do Congresso Nacional: I - resolver definitivamente sobre tratados, acordos ou atos internacionais que acarretem encargos ou compromissos gravosos ao patrimônio nacional; (...)", e depois ratificado e promulgado pelo Presidente da República.

Este procedimento dá vigência internacional e interna ao tratado, mas sendo vigente no ordenamento interno, resta saber qual hierarquia ocupa. A Constituição nos diz que pode o tratado internacional ser objeto de controle de constitucionalidade ${ }^{2}$, mas isto não resolve o problema da hierarquia, pois mesmo as Emendas Constitucionais estão sujeitas a tal controle ${ }^{3}$.

É a jurisprudência da Suprema Corte que soluciona o problema, no RE 80.004/SE, no bojo do qual entenderam os ministros, por maioria, que os tratados internacionais poderiam ser derrogados por lei posterior e fazer o mesmo com as leis anteriores, encontrando-se

$1 \quad$ 1."Uma pessoa é considerada representante de um Estado para a adoção ou autenticação do texto de um tratado ou para expressar o consentimento do Estado em obrigar-se por um tratado se: a) apresentar plenos poderes apropriados". Art. 7. Convenção de Viena sobre o Direito dos Tratados promulgada Decreto 7.030, de 14 de dezembro de 2009. Algumas pessoas são consideradas dispensadas de apresentar os plenos poderes, sendo consideradas plenipotenciárias pelo cargo que exerça, assim o item 2 da mesma convenção: "Em virtude de suas funções e independentemente da apresentação de plenos poderes, são considerados representantes do seu Estado: a) os Chefes de Estado, os Chefes de Governo e os Ministros das Relações Exteriores, para a realização de todos os atos relativos à conclusão de um tratado; b) os Chefes de missão diplomática, para a adoção do texto de um tratado entre o Estado acreditante e o Estado junto ao qual estão acreditados; c) os representantes acreditados pelos Estados perante uma conferência ou organização internacional ou um de seus órgãos, para a adoção do texto de um tratado em tal conferência, organização ou órgão."

$2 \quad$ CF, art.102, III, b.

3 "Não será objeto de deliberação a proposta de emenda tendente a abolir: I - a forma federativa de Estado; II - o voto direto, secreto, universal e periódico; III - a separação dos Poderes; IV - os direitos e garantias individuais." CF. Art. 60, § 4. Ver BULOS, Uadi Lammêgo. Curso de direito constitucional. 6 ed. São Paulo: Saraiva, 2011, p. 264-269. 
com elas em pé de igualdade, tendo hierarquia infraconstitucional. ${ }^{4}$ Neste sentido, leciona Mazzuoli (2011a):

havendo conflito entre tratado e lei interna, a solução é encontrada aplicando-se o critério da lex posterior derogat priori. Desde 1977 vigora na jurisprudência do STF este último sistema, em que o tratado, uma vez formalizado, passa a ter força de lei ordinária, podendo, por isso, revogar as disposiçóes em contrário, ou ser revogado (perder eficácia) diante de lei posterior. Em outras palavras, tratando-se de instrumentos internacionais comuns (à exceção dos tratados de Direitos Humanos), a jurisprudência do STF tem adotado a possibilidade de treaty override no Direito brasileiro, entendendo ser possível a superação de um tratado em virtude de edição de lei posterior incompatível - ainda hoje encontra amparo na jurisprudência da nossa Suprema Corte.

Desta forma, a hierarquia de que goza o tratado internacional no ordenamento brasileiro é a mesma atribuída à lei ordinária. É esta a atual posição do STF, merecedora, contudo, de crítica.

Há um enorme apego à velha ideia de soberania, que não quer ver sucumbir diplomas legais internos diante de internacionais. A celebração de tratados internacionais é ato de soberania, na medida em que o Estado o contrai por livre vontade, e democracia, uma vez que necessariamente deve passar pela aprovação do Congresso Nacional.

A tese acatada no julgamento do RE 80.004/SE, data venia, é tentativa de simplificar o complexo fenômeno de integração da ordem interna e internacional com a forma pronta e acabada do direito interno, como se semelhantes fossem.

A 'norma' internacional tem seus próprios meios de elaboração, irradiação de efeitos e revogação. Aceitar o treaty override 5 significa dizer que um Estado-parte pode revogar o tratado unilateralmente, sem a comunicação ao outro Estado-parte e sem fazer uso da denúncia - instrumento legítimo para revogação de tratado - e ao arrepio da convenção de Genebra sobre Direito dos Tratados (1969). A esse respeito, Alexandre Miguel (2012, p. 44) leciona:

Fácil seria burlar qualquer pacto internacional, se por disposiçôes legislativas internas fosse possível modificá-las. Nada obstante, muitas vezes o objeto do tratado internacional é o de justamente incidir sobre situaçōes que deveriam ser observadas no plano interno dos Estados signatários.

4 STF. Recurso Extraordinário n 80.004/SE, de 1/6/1977. Convenção de Genebra, lei uniforme sobre letras de câmbio e notas promissórias, aval aposto a nota promissória não registrada no prazo legal, impossibilidade de ser o avalista acionado, mesmo pelas vias ordinárias. Validade do Decreto-lei n. 427, de 22.01.1969. Embora a Convenção de Genebra que previu uma lei uniforme sobre letras de câmbio e notas promissórias tenha aplicabilidade no direito interno brasileiro, não se sobrepõe ela as leis do país, disso decorrendo a constitucionalidade e consequente validade do Dec.-lei 427/69, que institui o registro obrigatório da nota promissória em repartição fazendária, sob pena de nulidade do título. Sendo o aval um instituto do direito cambiário, inexistente será ele se reconhecida a nulidade do título cambial a que foi aposto. Recurso extraordinário conhecido e provido.

5 Instituto pelo qual o compromisso internacional perde a sua vigência diante da edição de norma interna (lei) que com ele conflite. 
Mais do que isso, se assim agirem os Estados, inviabilizado estará o Direito Internacional, construído sobre o alicerce da boa-fé, quedando-se ameaçado o desenvolvimento das relações interestatais, quiçá a paz entre as naçóes.

Parece mais acertada a posição de que o tratado tem força para revogar a norma interna infraconstitucional, mas que o contrário não é possível em uma teoria de prevalência da norma internacional.

\subsubsection{Teoria da Prevalência}

Sobre esta teoria explica Francisco Rezek (2008, p. 94) que a problemática não está no conflito entre o tratado e a lei anterior à sua promulgação, não havendo necessidade deste tratado recolher da ordem constitucional um benefício hierárquico, pois a mera introdução no complexo normativo pátrio ab-rogaria, pela regra Lexposterior derogat priori, a lei que lhe seja anterior. Destarte, o problema está no conflito com a lei ordinária posterior a ele, que, neste contexto, não teria a legitimidade de ab-rogar o tratado, tirando, desta feita, um valor hierárquico superior ao da lei ordinária.

Extrai-se ainda, da mesma obra de Francisco Rezek (2008, 94), exemplos da referida teoria no direito comparado, como se vê:
Constituição Francesa de 1985, art. 55: "Os tratados ou acordos devidamente ratificados e aprovados terão, desde a data de sua publicação, autoridade superior à das leis, com ressalva, para cada acordo ou tratado, de sua aplicação pela outra parte". Constituição da Grécia de 1975, art. 28, $\$ 1$ : "As regras de direito internacional geralmente aceitas, bem como os tratados internacionais após sua ratificação (...), têm valor superior a qualquer disposição contrária as leis”.
Constituição política da Argélia, texto de 1994, art. 75, $₫$ 22: “(...) os tratados e concordatas têm hierarquia superior à das leis”.

Um verdadeiro descompasso é notado entre a jurisprudência e a doutrina pátrias nesta tratativa. Isso porque, embora a jurisprudência recente da Suprema Corte seja no sentido da paridade, encontram-se na melhor doutrina fiéis defensores da prevalência dos tratados sobre as leis ordinárias, como Valério de Oliveira Mazzuoli. A despeito da jurisprudência da Corte Constitucional, este autor (MAZZUOLLI, 2011a, p. 342) entende que correto seria a utilização de referida teoria em nosso ordenamento, lecionando:
No nosso entender os tratados internacionais comuns ratificados pelo Estado brasileiro é que se situam num nível hierárquico intermediário, estando abaixo da Constituição, mas acima da legislação infraconstitucional, não podendo ser revogado por lei posterior (posto não se encontrarem em situação de paridade normativa com as demais leis nacionais).

Quanto aos efeitos práticos lançados no sistema nacional com a aceitação hipotética de tal teoria, segue o mesmo professor autor (MAZZUOLLI, 2011a, p. 343): 
Sob esse ponto de vista - de que, em geral, os tratados internacionais têm superioridade hierárquica em relação às demais normas de estatura infraconstitucional, quer seja tal superioridade constitucional, como no caso dos tratados de direitos humanos, quer supra-legal, como no caso dos demais tratados, chamados de comuns - é lícito concluir que a produção normativa estatal deve contar não somente com limites formais (ou procedimentais), senão também com dois limites verticais materiais, quais sejam: a) a Constituição e os tratados de direitos humanos alçados ao nível constitucional; e b) os tratados internacionais comuns de estatura supralegal. Assim, a compatibilidade (formal) da produção normativa doméstica com o texto constitucional não mais garante à lei validade no plano do Direito interno. Para que a validade (e consequentemente a eficácia) de uma lei seja garantida, deve ser ela materialmente compatível com a Constituição e com os tratados internacionais (de direitos humanos ou comuns) ratificados pelo Brasil. Em outras palavras, uma determinada lei interna poderá ser até considerada vigente por ter sido elaborada com respeito às normas do processo legislativo estabelecidas pela Constituição (e continuará perambulando nos compêndios legislativos publicados), mas não será válida se estiver em desacordo ou com os tratados de direitos humanos (que têm estatura constitucional) ou com os demais tratados dos quais a República Federativa do Brasil é parte (que têm status supralegal). Para a existência de vigência e concomitante validade das leis deverá ser respeitada uma dupla compatibilidade vertical material, ou seja, a compatibilidade da lei (1) com a Constituição e os tratados de direitos humanos em vigor no país e (2) com os demais instrumentos internacionais ratificados pelo Estado brasileiro.

Nesta senda, as normas internas deveriam passar não só pelo controle de constitucionalidade, mas também por um exame de convencionalidade.

Buscando justificar a prevalência do tratado internacional sobre a legislação doméstica, uma vez mais, Mazzuoli (2011a, p. 343) destaca trechos de legislaçóes infraconstitucionais brasileiras, verbis:

Aplica-se a lei brasileira, sem prejuízo de convençōes, tratados e regras de direito internacional, ao crime cometido no território nacional (art. $5^{\circ}$ do Código Penal Brasileiro de 1940); processo penal reger-se-á, em todo o território brasileiro, por este Código, ressalvados os tratados, as convençóes e regras de direito internacional (Código de Processo Penal, art. $1^{\circ}$, inc. I);

Os direitos previstos neste Código não excluem outros decorrentes de tratados ou convençôes internacionais de que o Brasil seja signatário, da legislação interna ordinária, de regulamentos expedidos pelas autoridades administrativas competentes, bem como dos que derivem dos princípios gerais, analogia, costumes e equidade (Lei $\mathrm{n}^{\mathrm{o}} 8.078$, de 11 de setembro de 1990 , art. $7^{\circ}$ ).

Em verdade, o Estado assume uma obrigação negativa ao celebrar um tratado internacional, observando a regra a que livremente se obrigou, abstendo-se, internamente, de produzir norma contrária. 
Acerca disto, pondera Alexandre Miguel (2012, p. 39):

Desde que aprovado um tratado internacional, o Poder Legislativo comprometese a não editar leis a ele contrárias. Se o Congresso Nacional dá sua aquiescência ao conteúdo de compromisso firmado, é porque implicitamente reconhece que, se ratificou o acordo, está impedido de editar normas posteriores que o contradigam. Assume o Congresso, por consequência, verdadeira obrigação legislativa negativa, ou seja, a de se abster de legislar em sentido contrário às obrigaçôes assumidas.

Assim, conhecendo a posição predominante no Supremo Tribunal, dela não se pode comungar.

\subsection{Tratados de matéria tributária}

O caso tributário é uma questão sui generis. Neste caso, o legislador optou de forma clara e expressa por dar primazia ao tratado em detrimento da legislaçáo infraconstitucional, porquanto "os tratados e as convençóes internacionais revogam ou modificam a legislaçáo tributária interna, e serão observados pela que lhes sobrevenha” (CTN, art. 98).

O que se extrai da leitura do dispositivo é que os tratados em matéria tributária estão acima das leis. Ora, se o tratado tem o poder de revogar ou modificar a legislação interna anterior a eles e devem ser observados pela que lhes sobrevenham, está ele em patamar hierárquico superior.

Portanto, pelo menos aqui, por disposição de texto expresso, vige a prevalência dos tratados sobre as normas infraconstitucionais.

De outro lado, os tratados afeitos à regulamentação de relações tributárias não logram a mesma sorte em conflitos com o texto constitucional, estando posicionados, portanto, entre a hierarquia das leis - superior a elas - e a hierarquia da constituição - inferior a ela -, hierarquia semelhante a do tratado internacional de direitos humanos não aprovado pelo quorum de emenda, dotado, assim, de status supra legal.

\subsection{Tratado Internacional de Direitos Humanos, aprovado pelo quórum qualificado}

Um novo conceito de Direitos Humanos nasceu após a segunda guerra mundial com a Declaração Universal dos Direitos Humanos de 1948, eis que durante a guerra o mundo assistiu o que talvez tenha sido o maior desrespeito já perpetrado contra a pessoa humana, em virtude do extermínio em massa de pessoas, cuja motivação se deu em razão de raça, crédulo, orientação sexual, opinião e etc.

Deste contexto histórico urgia a necessidade de se criar regras de respeito aos Direitos Humanos de forma universal, retirando do Estado a competência exclusiva para determinar quais eram os direitos da pessoa humana, tornando-os matéria de interesse internacional.

Neste sentido explica Flavia Piovesan (2009, p. 80):

A Declaração surgiu como um código de princípios e valores universais a serem respeitados pelos Estados. Ela demarca a concepção inovadora de que os direitos humanos são direitos universais, cuja proteção não se deve reduzir ao domínio 
reservado do Estado, porque revela tema de legítimo interesse internacional. A universalidade dos direitos humanos traduz a absoluta ruptura com o legado nazista, que condicionava a titularidade de direitos à pertença a determinada raça (a raça pura ariana). A dignidade humana, como fundamento dos direitos humanos e o valor intrínseco à condição humana, é concepção que, posteriormente, viria a ser incorporada por todos os tratados e declaraçôes de direitos humanos, que passaram a Direito Internacional dos Direitos Humano.

O que de mais marcante esta nova concepção de Direitos Humanos confeccionada pela Declaraçáo Universal dos Direitos Humanos trouxe para a ordem mundial, além da própria universalização do tema, foi a combinação do discurso liberal da cidadania com o discurso social, os quais, até então, caminhavam separadamente. A própria professora Flávia Piovesan (2009, p. 80) elenca as duas grandes inovaçóes trazidas pela Declaração, quais sejam: "a) parificar, em igual importância, os direitos civis e políticos e os direitos econômicos, sociais e culturais; e b) afirmar a inter-relação, indivisibilidade e interdependência de tais direitos."

Desta forma, o conceito de Direitos Humanos está baseado no respeito à dignidade da pessoa humana. Ele se consolida com uma formação interligada e interdependente entre os direitos fundamentais de todas as dimensôes ${ }^{6}$, estejam voltados à proteção seja dos direitos civis, políticos, sociais, culturais ou econômicos, seja dos direitos essenciais, não aceitando que nenhum deles seja desconsiderado ou menosprezado.

Atento a isto, o constituinte derivado brasileiro deu um passo incluindo no texto constitucional vigente, por meio da emenda constitucional no 45 , o parágrafo $3^{\circ}$ do art. $5^{\circ}$, com a seguinte redação:

Os tratados e convenções internacionais sobre direitos humanos que forem aprovados, em cada Casa do Congresso Nacional, em dois turnos, por três quintos dos votos dos respectivos membros, serão equivalentes às emendas constitucionais. (CF, 2015)

Esta mutação constitucional criou então uma terceira hierarquia possível para um tratado internacional em nosso país, qual seja: a de norma constitucional.

A melhor doutrina pátria, quando trata de hierarquia das normas, especialmente se referindo à estrutura de pirâmide trazida por Kelsen, não fala mais em norma constitucional como o topo da pirâmide, mas como bloco de constitucionalidade, justamente no sentido de incluir ao lado da norma constitucional originária a norma constitucional derivada e, também, o tratado internacional de direitos humanos aprovado pelo quórum qualificado. Assim, não paira qualquer dúvida a respeito da índole constitucional dos tratados internacionais de Direitos Humanos que tenham sido ou venham a ser incorporados com a observância de tal quórum.

Mais que isso, os valores trazidos nestes tratados são tão importantes que há quem entenda que mesmo o constituinte originário, outrora concebido como detentor

$6 \quad$ Quanto às dimensões dos direitos fundamentais, também tem se utilizado a expressão "gerações", mas parece mais adequado a primeira, uma vez que o termo gerações traz a ideia de superação, conquanto os Direitos Fundamentais não são superados pela a "geração" seguinte, mas complementado. Com maiores detalhes ver: FACHIN, Zulmar. Curso de direito constitucional. 6 ed. Rio de Janeiro: Forense, 2013, p. 222-223. 
de poderes ilimitados, não tem o poder de abolir tais direitos com a não recepção dos tratados internacionais de direitos humanos contraídos na ordem constitucional anterior. O Constitucionalismo vanguardista é que dá suporte a este argumento, defendendo alguns limites mesmo ao poder constituinte originário.

Vê-se, pois, que se por um lado é plausível falar em poder constituinte originário ilimitado quanto ao cunho formal, não é o mais acertado falar, nos dias de hoje, que não deve ele respeito às limitaçôes de cunho material. Como escreveu Uadi Lammêgo Bulos (2011, p. 398), na prática, mesmo o poder constituinte originário possui limites ideológicos, institucionais e substanciais, se desdobrando este último ainda em três modalidades específicas de limitações, quais sejam; transcendentais, imanentes e heterônomos.

Sendo de fundamental relevância para o estudo as limitações substanciais, heterônomas, as quais foram também objeto de conceituação por Uadi Lammêgo Bulos (2011, p. 398), em trecho citado a seguir:

Já os limites heterônomos condicionam o exercício do poder constituinte originário às normas de Direito Internacional. Assim, uma constituição não poderá ser criada ao arrepio dos preceitos reguladores de suas relaçôes internacionais. Tais limites são rubricados de heterônomos porque se escudam em atos normativos alheios ao Direito local. Derivam dos pactos, das responsabilidades e dos deveres assumidos entre Estados ou destes com a comunidade internacional em seu conjunto. Exemplo: a manifestação constitucional originaria de 1988 reconheceu, em seus trabalhos, o Tratado de Paz, celebrado após a Primeira e a Segunda Guerras Mundiais, que propiciou a dupla garantia dos direitos das comunidades grega e turca em Chipre, constante dos acordos de Zurique de 1960, bem como a obrigação da Áustria de abster-se de qualquer ato que prejudicasse sua total independência (Tratado de Saint-Germain de 1919).

Deste modo, reafirma-se, não pode nem mesmo uma nova Constituição Federal em nosso país afastar a aplicabilidade dos tratados de Direitos Humanos firmados pelo Estado antes dela, isto é, há uma impossibilidade de não recepção destes tratados.

E ainda por força do parágrafo terceiro do artigo quinto da Constituição Federal de 1988, incluído pela Emenda constitucional número 45, tais tratados têm hierarquia constitucional, não sucumbindo a qualquer norma nacional por critério hierárquico.

\subsection{Tratado Internacional de Direitos Humanos, quando não aprovado pelo quórum qualificado}

Quanto aos Tratados Internacionais de Direitos Humanos, reservou-se a eles a hierarquia de norma constitucional, caso observada a formalidade exigida pelo parágrafo $3^{\circ}$ do art. $5^{\circ}$ da Constituição Federal. Por outro lado, ainda no caso da não observância a esta formalidade, para parte majoritária da doutrina e para a jurisprudência do STF, esta espécie de tratado faz jus a tratamento diverso do tratado ordinário, onde se viu propor a adoção da tese da supralegalidade destes tratados.

Para bem definir tal tese, segue trecho do voto do Ministro Celso de Melo no RE 466.343/SP: 
Essa tese pugna pelo argumento de que os tratados sobre direitos humanos seriam infraconstitucionais, porém, diante de seu caráter especial em relação aos demais atos normativos internacionais, também seriam dotados de um atributo de supralegalidade. Em outros termos, os tratados sobre direitos humanos não poderiam afrontar a supremacia da Constituição, mas teriam lugar especial reservado no ordenamento jurídico. Equipará-los à legislação ordinária seria subestimar o seu valor especial no contexto do sistema de proteção dos direitos da pessoa humana.?

Tal entendimento já foi visto na Corte Constitucional com manifestação do Ministro Sepúlveda Pertence, no RHC no 79.785-RJ:

Certo, com o alinhar-me ao consenso em torno da estatura infraconstitucional, na ordem positiva brasileira, dos tratados a ela incorporados, não assumo compromisso de logo - como creio ter deixado expresso no voto proferido na ADInMc 1.480 com o entendimento, então majoritário - que, também em relação às convenções internacionais de proteçấo de direitos fundamentais - preserva a jurisprudência que a todos equipara hierarquicamente às leis. $\mathrm{Na}$ ordem interna, direitos e garantias fundamentais o são, com grande frequência, precisamente porque - alçados ao texto constitucional - se erigem em limitaçóes positivas ou negativas ao conteúdo das leis futuras, assim como à recepção das anteriores à Constituição (...). Se assim é, à primeira vista, parificar às leis ordinárias os tratados a que alude o art. $5^{\circ}, \S 2^{\circ}$, da Constituiçáo, seria esvaziar de muito do seu sentido útil a inovação, que, malgrado os termos equívocos do seu enunciado, traduziu uma abertura significativa ao movimento de internacionalização dos direitos humanos." [RHC no 79.785-RJ, Pleno, por maioria, Rel. Min. Sepúlveda Pertence, DJ 22.11.2002, vencidos os ministros Marco Aurélio e Carlos Velloso (o então Min. Presidente) ${ }^{8}$

É, então, de hierarquia superior às leis e abaixo da Constituição, estando alocado em patamar intermediário, que se encontra esta espécie de tratado, segundo voto do Ministro Gilmar Mendes no já citado RE 466.343/SP, como supralegal.

Entretanto, não parece ser este entendimento o mais acertado, dando as mãos à Flávia Piovesan na defesa da teoria da constitucionalidade material do Tratado Internacional de Direitos Humanos, sobretudo no sentido de que estes tratados já gozam de hierarquia constitucional por seu conteúdo material não havendo que se falar em sua submissão à formalidade de qualquer ordem. Ora, por quê? Uma forte tendência é percebida no direito doméstico e no internacional de cada dia mais zelar e proteger a dignidade da pessoa humana, pois não há dignidade sem vida, como não há vida sem dignidade.

7 STF. RE 466.343/SP. PRISÃO CIVIL. Depósito. Depositário infiel. Alienação fiduciária. Decretação da medida coercitiva. Inadmissibilidade absoluta. Insubsistência da previsão constitucional e das normas subalternas. Interpretação do art. 5, inc. LXVII e $\S \S 1^{\circ}, 2^{\circ}$ e $3^{\circ}$, da CF, à luz do art. $7^{\circ}, \S 7^{\circ}$, da Convenção Americana de Direitos Humanos (Pacto de San José da Costa Rica). Recurso improvido. Julgamento conjunto do RE n 349.703 e dos HCs n 87.585 e n 92.566. É ilícita a prisão civil de depositário infiel. Disponível em: <http://www.jusbrasil.com. br/jurisprudencia/busca?q=titulo: RE\%20466.343\%20SPEts=jurisprudencia >. Acesso em: 13/08/2011. 
A Carta Política Brasileira de 1988, inspirada pelo sentimento causado pela última grande guerra e a triste experiência vivida durante a ditadura militar que vigorou em nosso país, deu especial proteção à dignidade da pessoal humana, de forma antes não vista em nosso ordenamento constitucional. E ainda no $\$ 2^{\circ}$ do seu art. $5^{\circ}$ fez a seguinte ressalva, "não excluem outros decorrentes do regime e dos princípios por ela adotados ou dos tratados internacionais em que a República Federativa do Brasil seja parte” (CF, 2015).

E fundada neste ditame constitucional surge a Teoria Humanista que, certa da importância de se proteger de forma mais avançada e especial à dignidade da pessoa humana, fazendo uma interpretação teleológica e sistemática do dispositivo constitucional supracitado, acredita ter força de norma constitucional o Tratado Internacional que verse sobre Direitos Humanos, formando então o Bloco Constitucional, enquanto os demais tratados permanecem infraconstitucionais.

Importante lembrar que enorme diferença separa o tratado comum do tratado de direitos humanos. A esse respeito, preleciona Juan Antonio Travieso (1990, p.90):

Os tratados modernos sobre direitos humanos em geral, e, em particular, a Convenção Americana não são tratados multilaterais do tipo tradicional concluído em função de um intercâmbio recíproco de direitos para o beneficio mútuo dos Estados contratantes. Seu objeto e fim são a proteção dos direitos fundamentais dos seres humanos independente de sua nacionalidade, tanto frente a seu próprio Estado como frente aos outros Estados contratantes. Ao aprovar estes tratados sobre direitos humanos, os Estados se submetem a uma ordem legal dentro da qual eles, pelo bem comum, assumem várias obrigaçóes, não em relação a outros Estados, e sim pelos indivíduos sobre sua jurisdição. Portanto, a Convenção não só vincula os Estadospartes, mas outorga garantias às pessoas. Por esse motivo, justificadamente, não pode interpretar-se como qualquer outro tratado. (Traduzimos.) ${ }^{9}$

A Emenda Constitucional 45/2004, entre suas inovaçóes, acrescentou o $\$ 3^{\circ}$ no art. $5^{\circ}$ que determinou que os Tratados Internacionais de Direitos Humanos aprovados por 3/5 dos membros das suas casas do congresso em dois turnos de votação em cada casa teriam força de emenda constitucional. Tal inovação veio no sentido de acabar com a dúvida antes existente quanto à força constitucional destes tratados, como trabalhado no tópico antecedente.

Aqui se acredita, entretanto, que todo o tratado incorporado pelo direito pátrio versando sobre direitos humanos tem status de emenda constitucional, não desamparando sequer os tratados dessa natureza que tenham sido incorporados no direito interno antes da emenda constitucional 45/2004, como defende Flávia Piovesan (2009, p. 19):

$9 \quad$ No original: Los tratados modernos sobre derecho humanos em general, y, em particular, la Convención Americana no son tratados multilaterales del tipo tradicional concluídos em función de um intercambio recíproco de derechos para el benefício mutuo de los Estados contratantes. Su objeto y fin son la protección de los derechos fundamentales de los seres humanos Independiente de su nacionalidad, tanto frente a su próprio Estado como frente a los otros Estados contratantes. Al aprobar estos tratados sobre derechos humanos, los Estados se someten a um orden legal dentro del cual ellos, por el bién común, asumen varias obligaciones, no em relación com otros Estados, sino hacia los indivíduos bajo su jurisdicción. Por tanto, la Convencion no solo vincula a los Estados partes, sino que otorga garantias a las personas. Por esse motivo, justificadamente, no puede interpretarse como cualquier outro tratado. 
Reitere-se que, por força do art. $5^{\circ}, \S 2^{\circ}$, todos os tratados de direitos humanos, independente do quorum de sua aprovaçáo, são materialmente constitucionais, compondo o bloco de constitucionalidade. O quorum, qualificado está táo-somente a reforçar tal natureza, ao adicionar um lastro formalmente constitucional aos tratados ratificados, propiciando a "constitucionalização formal" dos tratados de direitos humanos no âmbito jurídico interno. Como já defendido por este trabalho, na hermenêutica emancipatória dos direitos há que imperar uma lógica material e não formal, orientada por valores, a celebrar o valor fundante da prevalência da dignidade humana. (grifamos.)

Ainda neste sentido Piovesan (2009, p. 19):

\begin{abstract}
À hierarquia de valores deve corresponder uma hierarquia de normas, e não o oposto. Vale dizer, a preponderância material de um bem jurídico, como é o caso de um direito fundamental, deve condicionar a forma no plano jurídico-normativo, e não ser condicionado por ela.
\end{abstract}

Esta teoria, muito embora ainda não tenha sido aplicada pela jurisprudência do Supremo Tribunal Federal, vem demonstrando ser forte tendência no direito internacional, sendo adotada por grande parte das Constituições modernas na América Latina. É o que parece mais acertado.

\title{
2.5. Hierarquia da Convenção de Roma
}

Ainda não foi apreciada pelo Supremo Tribunal Federal a hierarquia que tem em nosso país o Estatuto de Roma que instituiu o Tribunal Penal Internacional.

E não é missão fácil. Trata-se de um tratado internacional considerado por parte da doutrina como de matéria comum, tendo para estes a hierarquia de lei ordinária. Para outra parcela da doutrina é tratado internacional de Direitos Humanos, não internalizado pelo quórum qualificado, e aqui há outra divisão da doutrina, para uns com hierarquia supralegal conforme entendimento do Supremo Tribunal Federal, para outros hierarquia materialmente constitucional por interpretação do $\$ 2^{\circ}$, do art. $5^{\circ}$, da Constituição Federal ou ainda hierarquia constitucional dada pelo $\$ 4^{\circ}$, do art. $5^{\circ}$, da Constituiçáo Federal.

Garantindo um devido processo legal com ampla defesa, contraditório, prévia cominação legal, independência e imparcialidade do juízo, em um cenário antes despido de todas estas garantias fundamentais, é inegável o caráter de tratado de Direitos Humanos do Estatuto de Roma.

Em face deste caráter, só restam duas hierarquias possíveis a este tratado, a supralegal e a constitucional. Como já manifestado, parece mais correta a posição defendida por Flávia Piovesan, no sentido de ser todo tratado de Direitos Humanos aprovado pelo Brasil, de hierarquia constitucional, pois o que deve orientar a questão é o conteúdo material e não o formal, sendo por consequência o Estatuto de Roma também tratado de índole constitucional.

Destarte há também outro aspecto conduzindo tal tratado ao mesmo estágio hierárquico. O parágrafo quarto do artigo quinto da Constituição Federal brasileira, incluído 
pela Emenda Constitucional 45/2004 assim prevê: "o Brasil se submete à jurisdição de Tribunal Penal Internacional a cuja criação tenha manifestado adesão".

No ano da aprovação da emenda constitucional, o Brasil já havia ratificado a Convenção de Roma e a mesma já estava vigente interna e externamente em relação ao Brasil, não havendo porque o constituinte derivado incluir o parágrafo quarto se fosse para conferir à Corte (Tribunal) Penal Internacional tratamento já previsto no parágrafo terceiro, incluído pela mesma Emenda. Quis o constituinte derivado, por certo, dar tratamento peculiar à jurisdição internacional do Tribunal, colocando-a longe do alcance das leis, conferindo o status peculiar de seu poder, o de norma constitucional derivada.

\section{Considerações Finais}

Os tratados internacionais de Direitos Humanos recebem o status constitucional integrando o bloco de constitucionalidade, portanto - por força do $\$ 3^{\circ}$ do artigo $5^{\circ}$ da Constituição. Com efeito, segundo decisão do RE. 366.343, os tratados internacionais de Direitos Humanos não aprovados pelo quórum qualificado são considerados supralegais e os tratados de matéria tributária também o são por força da expressa disposição do artigo 98 do Código Tributário Nacional. E por interpretação majoritária da doutrina e jurisprudência pátria os tratados de matéria comum têm hierarquia ordinária.

Acreditando que o Estado. em ato livre de soberania. se obriga por meio da ratificação a cumprir o pactuado no tratado, está obrigado, portanto, a não produzir normas contrárias ao que se comprometeu nele, devendo, assim, fazer um exame de convencionalidade (MAZZUOLLI, 2011a) das leis. Destarte, o tratado internacional de matéria comum está colocado acima das leis internas devendo ser observados por elas, só sucumbindo em um conflito com norma constitucional.

De outro lado o tratado internacional de Direitos Humanos, independente do quórum de sua aprovação, tem pelo seu conteúdo status constitucional. Não estando hierarquicamente abaixo da norma constitucional. Em especial o Estatuto do Tribunal Penal Internacional, que integra o texto constitucional a partir da Emenda Constitucional 45/2004, detêm esta força.

\section{Referências}

AMBOS, Kai. A parte geral do direito penal internacional: bases para uma elaboração dogmática; tradução Carlos Eduardo Adriano Japiassú, Daniel Andrés Raisman; revisão Pablo Alflen, Fabio D’Avila; atualização Kai Ambos; Miguel Lamadrid. São Paulo: Revista dos Tribunais, 2008.

; MALARINO, Ezequiel; WOISCHNIK, Jan (coords.). Dificuldades jurídicas e políticas para a ratificação ou implementação do Estatuto de Roma da Corte Penal Internacional:contribuições da América Latina e Alemanha. São Paulo: IBCCRIM Instituto Brasileiro de Ciências Criminais, 2006.

ARAÚJO, José Carlos Evangelista de; LEHFELD, Lucas de Souza. Os tratados internacionais de Direitos Humanos no âmbito da Emenda Constitucional 45/2004. In: BAPTISTA, Luiz Olavo; MAZZUOLI, Valerio de Oliveira (Orgs.). Direito 
internacional dos Direitos Humanos. Direito internacional dos direitos humanos: temas diversos. São Paulo. Revista dos Tribunais. (Coleção Doutrinas essenciais: Direito Internacional. v. 3.)

BRASIL. Código Tributário Nacional. Disponível em: <http://www.planalto.gov.br/ ccivil_03/LEIS/L5172.htm>. Acesso em: 14 set. 2015.

BRASIL. Constituiçáo da República Federativa do Brasil. Promulgada em 05 de outubro de 1988.

BRASIL. Supremo Tribunal Federal. RE466.343/SP. Disponível em: <http://www.jusbrasil. com.br/jurisprudencia/busca?q=titulo:RE\%20466.343\%20SP\&s=jurisprudência $>$. Acesso em: 13/08/2011.

BULOS, Uadi Lammêgo. Curso de direito constitucional. 6 ed. São Paulo: Saraiva, 2011. ESTATUTO DE ROMA. Ratificado pelo decreto 4.388 de 25 de setembro de 2002.

EURICH, Elisabete; QUADROS, Neudy Juliano. O conflito entre normas internas e internacionais no ordenamento jurídico brasileiro: uma tomada de decisão do legislador constituinte. Disponível em: <http://www.oabpr.com.br/ revistaeletronica/revista03/77-91.pdf>. Acesso em: 11/07/2011.

FACHIN, Zulmar. Curso de direito constitucional. 6 ed. Rio de Janeiro: Forense, 2013.

FLORES, Andréa; LOPES, Jodascil Gonçalves. Manual de direito penal. Coleção Ícones do Direito. Coord. PUCCINELLI JR., André. São Paulo: Saraiva, 2015.

JAPIASSÚ, Carlos Eduardo Adriano. O Tribunal Penal Internacional. A internacionalizaçáo do direito penal. Rio de Janeiro: Lumes Júris, 2004.

KARSAI, Krisztina. A competência originaria "oculta" do Tribunal Penal Internacional: sobre o art. 70 do Estatuto de Roma. Ciências Penais: Revista da Associaçáo Brasileira de Professores de Ciências Penais. São Paulo, ano 5, v. 9, p. 114-135, jul.-dez. 2008.

KELSEN, Hans. Derecho y paz em las relaciones internacionales. Ciudad Del México: Fontamara, 1996.

. Teoria geral de direito e do Estado. São Paulo: Saraiva, 2008.

. Teoria pura do direito. 8 ed. São Paulo: Saraiva, 2009.

MAZZUOLI, Valerio de Oliveira. Curso de direito internacional público. São Paulo: Revista dos Tribunais, 2011.

. Teoriageral do controle de convencionalidade no direito brasileiro. Disponível em: <http://www2.senado.leg.br/bdsf/bitstream/handle/id/194897/000861730. pdf? sequence=3>. Acesso em: 14 set. 2015.

. O Tribunal Penal Internacional e o direito brasileiro. 3 ed. rev. e ampl. São Paulo: Revista dos Tribunais, 2011 (b). (Coleção direito e ciências afins; v. 3).

MIGUEL, Alexandre. A constituiçâo brasileira e os tratados internacionais de Direitos Humanos. In: BAPTISTA, Luiz Olavo; MAZZUOLI, Valerio de Oliveira (Org.). Direito internacional dos Direitos Humanos. São Paulo. Revista dos Tribunais, 2012.

MIRANDA, Jorge. Curso de direito internacional público. 3 ed. São Paulo, 2009.

PEREIRA, Bruno Yepes. Curso de direito internacional público. São Paulo: Saraiva, 2006. 
PEREIRA, Marcelo Augusto Paiva. O Tribunal Penal Internacional e a Constituiçáo Federal. Disponível em: <http://www.lfg.com.br/public_html/article.php?story= 20080509093736745>. Acesso em: 10/09/2011.

PEREIRA, Ricardo de Souza. A imprescritibilidade penal nos crimes de competência do Tribunal Penal Internacional. No prelo. Dissertação (mestrado). Pontifícia Universidade Católica de São Paulo, São Paulo, 2013.

PIOVESAN, Flávia. Temas de Direitos Humanos. São Paulo: Saraiva, 2009.

PRADO, Luiz Regis; CARVALHO, Érika Mendes de; CARVALHO, Gisele Mendes de. Curso de direito penal brasileiro. São Paulo: Revista dos Tribunais, 2013.

PRADO, Luiz Regis. Tratado de direito penal brasileiro: parte geral: volume 1. São Paulo: Revista dos Tribunais, 2014 (Coleção tratado de direito penal brasileiro; v. 1.)

PUCCINELLI JR. André. Curso de direito constitucional. 5 ed. São Paulo: Saraiva, 2015.

REALEJÚNIOR, Miguel.Aresponsabilidadepenal da pessoal Jurídica. Responsabilidade penal da pessoa jurídica: em defesa da imputaçáo penal subjetiva. São Paulo: Revista dos Tribunais, 2001.

REZEK, José Francisco. Direito internacional público. São Paulo: Saraiva, 2008.

SILVA, Roberto Luiz. Direito internacional público. Belo Horizonte: Del Rey, 2002.

TAIAR, Rogerio. Direito internacional dos Direitos Humanos: uma discussáo sobre a relativizaçáo da soberania face à efetivaçáo da proteçáo internacional dos direitos humanos. Tese (Doutorado). Faculdade de Direito da Universidade de São Paulo, São Paulo, 2009.p. 253 apud LUZ, Nelson. O problema da soberania e o direito das gentes. Revista da Faculdade de Direito da Universidade Federal do Paraná, v. 1, p. 170-177. Paraná: UFPR, 1953.

TRAVIESO, Juan Antonio. Derechos Humanos y derecho internacional.Buenos Aires: Heliasta. 1990.

\section{Andrea Flores}

andreaflores.adv@gmail.com

Mestre e Doutora pela PUC/SP. Professora de Direito Penal na graduação e pós-graduação UFMS e UCDB. Professora colaboradora do Mestrado em Direito da UFMS.

\section{Jodascil Gonçalves Lopes}

jodascil@hotmail.com

Mestre em Direitos da Personalidade pela UNICESUMAR, Especialização em Direito Constitucional e Especialização em Direito Penal e Direito Processual Penal. Graduando do Curso de Filosofia na UFMS. 